\title{
From Policy to Practice: Roma Education in Albania and Sweden
}

\author{
Helen Avery ${ }^{1,2,5}$ • Itena Hoxhallari ${ }^{3,4}$
}

Published online: 4 January 2017

(C) The Author(s) 2017. This article is published with open access at Springerlink.com

\begin{abstract}
This paper aims to make a contribution to recentering practice- and practitioner-oriented issues in Roma education studies. Gaps can be observed today between conditions of educational work in practice and the ways education is understood in mainstream academic discussions, compounded by the fact that educational workers in the field have limited access to academic environments. Also, as a subject dealing with minorities, education for Roma and Roma communities tends to occupy a marginal position in academic departments of Education. Inversely, in Roma studies, focus often lies on culture or history, and education is mainly considered through the lens of identity. This means that many important experiences in Roma educational work remain silent, and significant aspects of practices are not sufficiently shared across contexts. In this paper, experiences from education projects in Albania and Sweden are presented and considered against the background of Roma education policies in these countries generally. An analysis is made of the ways these projects directly or indirectly connect to local academic structures. Finally, suggestions are made of potential strategies for developing practice- and practitioner-driven research in this area, to make relevant experiences more accessible across linguistic and national borders.
\end{abstract}

\footnotetext{
$\bowtie$ Helen Avery

Helen.Avery@ju.se; Helen.Avery@cme.lu.se

Itena Hoxhallari

http://www.caf-albania.org

1 School of Education and Communication, Jönköping University, Jönköping, Sweden

2 Center for Middle Eastern Studies, Lund University, Lund, Sweden

3 Sociology Department, Tirana University, Social Sciences Faculty, Tirana, Albania

4 Children Are the Future, Tirana, Albania

5 CMES, Finngatan 16, 22362 Lund, Sweden
} 
Keywords Roma education $\cdot$ Albania $\cdot$ Sweden $\cdot$ Equity $\cdot$ Research approaches

\section{Introduction}

From a legal point of view, the situation of Roma in Europe has improved these past decades, as minority rights (Elias 2010) to language and culture have been guaranteed. Important work is being carried out internationally to support recognition of Roma and develop better conditions. At national levels, in both Albania and Sweden, legislation guarantees access to education for all residents. Nevertheless, the proportion of Roma to continue education beyond compulsory school is much lower than for the majority populations (Miskovic and Curcic 2016). Discrimination and prejudice are still widespread (Kamberi et al. 2015). At the same time that economic conditions have a negative impact on school achievement (Miskovic and Curcic 2016), poor education is likely to affect income opportunities over the life-course of individuals and families. But the economic structures that cause poverty and inequity are a much more complex and pervasive set of issues than minority rights, and also more difficult to transform.

Roma are a minority in European societies, which means that it becomes more difficult to find inspiring role models close at hand, showing that it is possible to pursue studies at higher level or access high status positions in society (Garaz 2014). Students may not find such role models in their own families, and they are unlikely to find them among the teachers at school. Similar difficulties concern the various types of educators, assistants, social workers or interpreters working with Roma students and their families. There is thus a general lack of cultural bridging, as well as of role models showing empowering pathways. Besides the lack of subject teachers with a Roma background, there are few qualified mother tongue teachers, and teachers who could work as tutors in the mother tongue.

Legal stipulations on minority rights do not alone suffice to address basic issues of equity and social justice, nor do existing educational provisions appear to offer adequate support to change this state of affairs. This is why comprehensive strategies to improve education for Roma deserve special attention, going beyond school as a self-contained institution and involving the wider communities. This paper will examine examples of policy and practice in the contexts of two European countries with Roma minorities: Albania and Sweden.

Albania and Sweden are in certain respects quite different, since Albania has one of the lower GNPs in Europe, while Sweden has one of the highest. At the same time, both countries are relatively small, have long traditions of state planning, and share a concern with equity coupled to expectations that state policies should contribute to welfare and wellbeing. Despite living in a more affluent nation, educational challenges for Roma in Sweden on many points resemble those in Albania. Comparing the focus of policies in the two countries as well as implications for Roma education can therefore shed light on assumptions that are taken for granted in either context. 


\section{Roma Communities in Albania and Sweden}

The Roma community in Albania is one of the oldest in Europe, and its existence has been documented from the thirteenth century. Roma in Albania are officially recognised as a cultural minority (Baraku and Hoxhaj 2015), composed of five major groups: Meçkar, Çergar dhe Kurtof, Karbuxhi/Arrlij, dhe Bamill. These groups have significant differences among themselves, in terms of cultural customs and needs, as well as in terms of social integration in Albanian mainstream society. No precise figures exist concerning the number of Roma in Albania, and estimates range from 8301 (INSTAT 2011) to approximately 150,000, according to several Roma organisations and other sources. From 1999 Albania has started the efforts to protect the rights of national minorities and to support their integration and development in the country, through various means, such as joining the Roma Decade (2005-2015) National Action Plan. ${ }^{1}$ However, despite a number of national and international programmes, the Roma community still remains marginalised in many respects, and young people are at risk of social exclusion.

Presence of Roma in Sweden has been documented from the early sixteenth century. The older groups in Scandinavia mainly belong to Kale (from Finland) and Kalderash. As citizens, Roma are protected by overarching legislation prohibiting discrimination, but also temporary residents benefit from certain guarantees to access education, health care or various social services. For instance, undocumented children residing in the country are in principle entitled to education by Swedish law (SFS 2010:800 Chapter 29, Sects. 2-6), in accordance with Article 2 of the supplementing Protocol No 1 to the European Convention and Articles 28 and 29 of the UN Convention on the Rights of the Child. However, the interpretation of the right to education has been contested with regard to the children of unemployed Roma arriving from EU countries. ${ }^{2}$

Since 1999, and in accordance with the European Framework Convention, Roma have the status of national minority in Sweden, strengthening the right to maintain and develop language and culture. However, increased access to administrative services in the other minority languages Sami, Mienkele and Finnish is geographically connected to the regions these language are spoken. Such entitlements do not benefit Roma, who cannot make claims on the basis of territoriality or land rights. Provisions for improved access to citizenship, participation or special representation are therefore marginal. On the other hand, the cultural and linguistic rights have been accompanied by state funding, the creation of Roma institutions and also assigning responsibility for studying Roma issues in higher education.

\footnotetext{
1 www.romadecade.org Accessed 25 October 2016.

2 The matter has been the subject of some controversy. According to the Swedish government's website on human rights, the right to education does not apply to children who are citizens of EU countries and who are residing in Sweden for the authorised period of three months. http://www.manskligarattigheter.se Accessed 25 October 2016. On the other hand, in a decision from February 2016, the Swedish Schools Inspectorate ruled that a Roma pupil who had stayed longer than three months fell under the category of being undocumented, and therefore had the right to receive schooling. Nevertheless, commenting this decision, the Association of Swedish Municipalities does not believe that the law refers to unemployed EU migrants. http://sverigesradio.se/sida/artikel.aspx?programid=105\&artikel=6378528 Accessed 25 October 2016.
} 
In line with the overall legislation on national minorities in Sweden, a number of Roma organisations and also researchers in higher education obtain government support to develop Roma language and culture. Such work contributes to shaping symbols of unity and documenting a shared history of discrimination. By attending events for Swedish national minorities and participating in networks with the other minorities, Roma representatives and teachers get a stronger position for political influence. These networks also help gain a better understanding of structural conditions affecting minorities more generally, rather than as just concerning Roma. Another positive initiative has been a programme for training mediators at Södertörn university college (Rodell Olgaç and Dimiter-Taikon 2016), which has thereby also connected work at schools with the research environment.

Approximately 50-100,000 Roma live in Sweden today, but as in Albania, exact numbers cannot be found. Ethnic registration is illegal, and statistics are uncertain at the national level. Since several studies have been conducted by the municipalities, a clearer picture can be gained by looking at the situation more locally. The southern part of Sweden with the town of Malmö will be taken as an example in the following. In 2008, an estimated 6000-7000 Roma lived in Malmö, divided into six groups: Lovara, Kalderasha, Rumungri, Arli, Gorbet and Kalé. The Roma in this city originated from eight different countries besides Sweden (Malmö Stadskontor 2008). While the communities participating in the consultation for the Malmö report were well established in the city, over the past years there has been an additional immigration of a small but very visible group of so-called 'EU migrants', coming from Balkan countries that have entered the EU more recently, as well as vulnerable Roma from southern European countries affected by the recent economic crisis. The situation of the newly arrived is highly precarious (Center for Social Rights 2016), and questions of territoriality thus remain significant also today. For immigrants generally, and Roma in particular, renting accommodation, obtaining formal work contracts, gaining residency status and entering the social security system are all interconnected. The process is rendered difficult by administrative regulations and through the compounded obstacles of poverty, language barriers, lack of formal vocational qualifications recognised in Sweden and the rise of anti-immigrant and anti-ziganist sentiments.

\section{Challenges in Roma Education}

In Albania, education is one of the four main prioritised areas where attention has been focused, but still the level of illiteracy among the Roma community is the highest compared to the non-Roma population. Thus the Civil Society Monitoring Report estimates the illiteracy among the Roma population at about $40 \%$, compared to $1.6 \%$ of the country average (Cabiri et al. 2013). Some of the measures taken in the framework of governmental policies have only had a very slight positive impact, and Roma access to education continues to be very low (European Commission 2011, 2015; Curcic et al. 2014).

Education work in communities with a considerable number of Roma students faces different types of difficulties in Albania. An important issue is that teaching frequently lacks active and interactive teaching methods and techniques that can 
make the lesson hour attractive, to increase student participation, learning and results. In some cases, teachers do not have the proper qualification or professional competencies, which makes teaching and learning more difficult. A shared pedagogical understanding is lacking, making it more difficult to carry out school development work. Parents are seldom able to help their children with the schoolwork. Resources and infrastructure are lacking in poorer areas, and there is certain segregation in schooling connected to the housing situation (cf. Xhillari and Cici 2016). A number of positive developments have been witnessed though, and the European Commission notes that government allocations for Roma housing have tripled (European Commission 2015).

In Albania, special programmes are intended to improve access of vulnerable groups to the vocational training programmes. Thus Roma youth have been able to register on these programmes, even if they had not completed compulsory education. However, lack of basic education became a problem in completing the vocational programmes, and another major problem was that only $30 \%$ of vocational students and only $3.5 \%$ of short-term vocational course trainees were able to find a job after the programme, according to statistics from 2015 (Xhumari and Dibra 2016).

As in Albania, the greatest and most obvious obstacle to education for Roma youth in Sweden today is poverty. This is particularly noticeable among the recently immigrated groups, where young people need to contribute economically to the family as soon as possible. The latest arrivals in Sweden from EU countries in the Balkans, and from countries like Spain witnessing an economic crisis-the so-called 'EU migrants' - have provoked a rise in violent anti-ziganism, as well as reactions of solidarity. Despite a discourse of free mobility within the EU, newcomers find it exceedingly difficult to rent homes in their own name, set up bank accounts or be employed with regular contracts.

Poverty and access to housing is also an issue for established groups, living in segregated neighbourhoods and attending low-status schools where teachers struggle to meet the students' needs. In such neighbourhoods we can observe a process of residualisation and "white flight", where the weakest and most vulnerable groups stay, compounding the learning difficulties in the schools, while more successful students leave to study at higher status schools elsewhere (Bunar 2010; Obucina 2014; Scarpa 2015). Disparities and gaps are widening between schools in wealthier neighbourhoods and those in poorer areas (Stigendal and Östergren 2013). In the poorer areas, teachers struggle with insufficient resources and a concentration of pupils with greater needs. These tendencies are further driven by accountability, tying allocation of resources to individual pupils. The recent emphasis on assessment, a discourse on tracking, and a subsequent dismantlement of the previous system for continuous adult education have all reinforced the sorting function of the school system in Sweden (Alexiadou et al. 2016).

\section{Mother Tongue Support: The Example of Sweden}

The Framework Convention for the Protection of National Minorities and the European Charter for the Protection of Regional or Minority Languages were 
ratified by the Swedish Parliament in 2000, recognising Finnish, Meänkieli and Sami as minority languages (Government Bill 1998/1999, p. 143), and recognising the Sami, Swedish Finns, Tornedalians, Roma and Jews as national minorities. Through the Language Act of 2009 (SFS 2009a:600), Romani Chib and Yiddish have been recognised as non-territorial minority languages. Finally, the Act on National Minorities and National Minority Languages (SFS 2009b:724; Government Offices of Sweden 2013) provides additional protection for the national minorities in Sweden, including the Roma. Educational support measures for Roma, as well as for immigrant pupils, focus language, in line with research that underlines the importance both of medium of instruction and language policies more generally (cf. May 2014).

Two forms of support measures in the Swedish school system concern Roma students more particularly. One is mother tongue teaching of both national and immigrant minority languages. The other is tutoring in the mother tongue for newly arrived students. A pupil who has a custodian with a mother tongue other than Swedish should be offered mother tongue tuition in this language if the language is the pupil's daily means of interaction in the home and the pupil has basic knowledge of the language. Mother tongue tuition in a national minority language should be offered even if the language is not the pupil's daily means of interaction in the home. (SFS2010:800; 2014:458, Chapter 10, Sect. 7). Mother tongue instruction may not be given in more than one language, except for Roma pupils arriving from abroad. The law further stipulates that "A pupil shall receive tutoring in his/her mother tongue, if the pupil needs it." (SFS 2011:185, Chapter 5, Sect. 4, author's translation).

Nevertheless, despite the right to access sufficient support inscribed in the legal governing documents, resources allocated to support measures are in fact minimal, and mother tongue teaching is also marginalised in the schools (Rodell Olgaç and Dimiter-Taikon 2013; Avery 2015). An additional problem is that languages taught as "mother tongue" are implicitly assumed to mirror characteristics of Swedish, so that the syllabi for minority languages contain ambitious learning objectives in standard written forms that do not correspond to sociolinguistic realities. Even when qualified teachers are found, there is some likelihood that these teachers will have a different background and in fact speak different languages than their students and their families. Far from being a single community with a standardised language, there is a considerable linguistic diversity of Roma groups living in Sweden. Thus in the Malmö report (Malmö Stadskontor 2008) and the report commissioned by the Delegation for Roma Issues (Delegationen 2010) it appears that not only was there an insufficient number of qualified mother tongue teachers able to teach Romani in Malmö, but importantly, the variety of Romani these teachers were competent in did not match the dialects of their students.

A further complication is that as a consequence of the minority rights, Swedish legislation gives a privileged position to so-called national minorities, compared to immigrant minority groups. In practice, however, this aspect of the legislation is particularly hard to apply. It is socially and emotionally problematic for schools to attempt to create hierarchies among the underprivileged children and young people living in segregated neighbourhoods with a high proportion of immigrants. Importantly, granting the extended linguistic and cultural rights expressed in 
legislation of Roma as a national minority would suppose considerable investment in developing literacy in the communities in Romani languages, and training professionals in different areas capable of working in these languages. Similar contradictions between the ambitious learning objectives and limited resources that are allocated can be seen with respect to the other national minority languages.

\section{Examples of Community Engagement in Educational Development Projects}

Despite the challenges in Albania, some positive cases of supporting Roma education have been identified, ${ }^{3}$ one of which is "Educating parents and children by learning together", in Drizë village, Fier, Albania, supported by the Roma Education Fund. In this small village inhabited by 300 families, the majority of the population is Roma and is illiterate. Through this project, where parents and children learn together, some positive elements and mutual benefits for children and for parents have been experienced. They not only learn together how to read and write, but in this way children have a better support from their parents as they become more aware of the importance of education and also gain confidence that the future of their children will be improved. In the implementation of this project there have also been challenges, one of which is that fathers are less involved, and compared to mothers, they are finding studying more difficult.

Another positive experience that has been implemented during the last three years in the same region (Fier) is the initiative of the Roma particularly in Drizë and Baltëz. A community bridging initiative is supported by OSFA and OSF Budapest. There is an agreement with the Local Government, which offers an office for a person so that he/she can serve as a mediator between Roma families/Roma community and the various institutions, such as schools, employment agencies, and health or social institutions. The government does not offer any extra financial support, but supports the initiative by keeping the mediator as part of its institution, thereby providing official legitimacy and an organisational basis.

The project "Improving and Promoting Education and Training for Roma Children at National Level", was implemented during the year 2011-2012 by the Roma organisation Rromani Baxt Albania (RBA), with the financial support of the Roma Education Fund. The project was implementetd in the localities of AlliasKinostudio (Tirana, where approximately 300 Roma families live) and Baltëz (Fier, about 250 families). The main aim of the project was to increase participation in pre-school education, to provide extra-curricular support to Romani pupils in primary education, and to raise awareness among Romani parents about the importance of their children's education. As a result of this project 53 children from an expected 60 were enrolled in public primary schools. All 105 children from the concerned age groups attended after-school instruction centres of the implementing organisation, and all of which advanced to the next grade. Other activities of the project included supporting parents to complete the documents needed to enrol their children in school.

\footnotetext{
3 The information provided is based on field visits and interviews with Roma community representatives, leaders and Roma organisations.
} 
A similar project supporting education among Roma community in Albania has been "Educational Support in Kuçova, Grabian, Elbasan and Levan", implemented by the Union for Development and Integration of the Romani Minority in Albania "Amaro-Drom". Some of the main outcomes of the project were: 200-250 children (of which approximately 110 Roma) aged 3-6 years accessed quality inclusive preschool education (priority given to marginalised Romani children); Increased number of six-year-old children enrolled in first grade of primary education; $10-15$ Romani children aged 14-18 years participated in extracurricular courses in subjects where additional support was necessary; 350-400 parents' awareness increased about importance of education. Additionally the project resulted in an increased number of children with complete civil registration documents; and 10 educators and 6 teachers increased their knowledge and skills for working in a multiethnic environment.

Common factors for these promising projects are the central role played by Roma civil society organisations, close collaboration with the families, and supporting parents as well as the children.

Very similar conclusions concerning the importance of community engagement can be drawn from the Swedish context. In the example of Malmö, the Malmö report (Malmö Stadskontor 2008) investigated how Roma communities perceived the various projects that were conducted in the town. Fifteen Roma associations were active in Malmö at the time. The most pressing problems which were raised with respect to education concerned lack of employment and precarious working conditions in the community at large, poor housing conditions and the fact that only a small proportion of Roma girls finished compulsory school with pass marks. Despite several positive examples, the report stresses that the investigated projects would have worked better if they had been discussed with the concerned students and families to start with, and better still, if objectives had been formulated by the Roma themselves, rather than imposed from above. Those projects which were developed collaboratively were according to the report also the most successful, and had the greatest impact. However, project participants found it problematic that projects were conducted for limited periods, and that long term commitment was lacking. A further problem identified by participants was that the starting point for many projects was an assumption that Roma behaviour should change, rather than taking a more open approach to the situations that were considered.

Findings of an interview study with parents and teachers in the Malmö area (Liedholm and Lindberg 2010) largely confirm the 2008 Malmö study. In the 2010 report it appears that well-educated tutors are needed with language skills, but also with pedagogical knowledge and knowledge of the school subjects. Tutors are needed as a regular resource in education, not just as special support. The dialects of Romani spoken by mother tongue teachers do not match the dialects that the children are familiar with. Parents' unemployment and low expectations among teachers are mentioned as obstacles to school achievement. Liedholm and Lindberg (2010) further underline that the Roma associations in Malmö could be a valuable resource, but most schools do not collaborate with the associations. Studies in other areas of Sweden show similar patterns, and notably a frustration among Roma parents over insufficient dialogue with teachers (Rodell Olgaç and Dimiter-Taikon 
2013). This suggests that there is a great potential for progress, by more actively and consistently including parents and the community in educational work.

In view of the positive experiences reported from work conducted by small-scale Roma associations such as those working in the Malmö area, it is worrying that government subsidies for associative work have been reduced. There are today numerous targeted projects in the Malmö region, but in targeted projects outcomes are tightly defined in advance (for instance in terms of preventive health work, gender emancipation, or school achievement). This leaves little space for openended dialogue and community participation in defining objectives. At the same time, the Malmö Commission has placed focus on the need for socially sustainable urban development (Stigendal and Östergren 2013). In the expressed aims, however, there is a contradiction between the top-down nature of monitoring and steering instruments that are developed, ${ }^{4}$ and the call for greater involvement of children and parents in educational work put forward by the Commission.

\section{The Position of Academic Research}

Recognition of Roma rights at European and national levels has led to increasing interest in Roma issues and has contributed to the creation of national programmes and policies. Directly or indirectly, academic research on Roma issues has been informed by this governance perspective, and a body of research has been driven by generalising theory or by administrative considerations. Today, we also find research related to national and European minority policy, and to linguistic rights. But to improve conditions in education and other aspects of the lives of Roma communities, it would seem indicated to increasingly develop needs-driven research (cf. Kelly and Van der Riet 2001).

In Albania, Roma studies do not have a strong position in higher education, but the situation is evolving. Due to the efforts of civil society organisations in cooperation with public universities, there are some positive cases, one of which is the establishment of the Roma cathedra at the faculty of foreign languages in the city of Elbasan city. This academic year (2015-2016) 12 Roma students are studying the Roma language there. The challenges that this group and this programme face have to do with the fact that the professors of Roma Language do not have pedagogical degrees and they face difficulties in the instruction and curricula development process. What is considered as an urgency by Roma representatives is therefore the issue of professional development of the professors of Romani language.

In the Albanian context, in order to have positive and long lasting improvements in the education, development and integration of the Roma community, a comprehensive and research-based approach and intervention are necessary. But our experience shows that to benefit from the knowledge of the communities, on the one hand, and to avoid imposing top-down policies, on the other, community based

\footnotetext{
${ }^{4}$ http://malmo.se/Kommun-politik/Socialt-hallbart-Malmo/Om-socialt-hallbart-Malmo/Continuing-workfor-a-socially-sustainable-Malmo.html Accessed 25 October 2016.
} 
and national policies or strategies should be developed through a participatory approach where the voice of Roma communities are well represented.

Sweden is often presented internationally as exemplary in the area of human rights. However, the country's track record is not equally positive in the area of minority rights, and includes some dark chapters in recent history, such as laws preventing schooling, forced sterilisations and placement of Roma children in foster care. Residence or entry into the country has been prohibited during certain periods, most recently from 1914 to 1953 , thereby closing the door to Roma refugees from Nazi exterminations (Ministry of Culture 2014). Against this painful background, part of contemporary Swedish research has been concerned with dealing with the historical persecution of Roma in Sweden. The situation today is more complex, and could maybe best be summarised by saying that it is characterised by double - or multiple-standards. Issues of developing language and culture are prioritised through the national minority status. By contrast, research in education receives less attention. A review of publications listed in the Swedish database Swepub using the search terms Roma and education (Romer, utbildning) suggests that practitioneroriented research in education is fragmented, although a few studies can be found in contexts such as work on culturally diverse classrooms (see for instance Rodell Olgaç 1999).

Using scientific rationales in research is not unproblematic. Fixed categorisations are in quantitative methods employed to obtain measurements that are compared over time. Implicitly, the characteristics of categories such as 'Roma' are assumed to be constant over time and space. By contrast, and by avoiding fixed and essentialising categorisations, ethnographic methods open the possibility for considering transformations and dynamic dimensions of a situation.

Earlier Swedish investigations tried to establish clear definitions of what exactly is to be considered Roma, and where to draw the line towards other categories such as travellers (tattare) or towards ambulatory populations (Palosuo 2008). Although research today is not openly based in race theories, the categorisation process which is involved in systematic nationwide research, as well as in several administrative procedures, entails similar risks. The intrinsic logic of metrics affects both the conceptualisation of the problems and how people are seen (cf. Bacchi 2007; Gorski 2012). An example is the comprehensive socio-medical 'Gypsy Study' that was carried out by Swedish authorities in the early 1960s. The investigation created a type of scientific perspective and description of the situation, where authorities' work is represented as legitimate and helpful, since it conforms to regulations. By the same token, the Swedish Roma are represented as 'problematic' and as deviating from established standards (Ohlsson Al Fakir 2015). Thus there is a fundamental tension between any transformative aims - that is, to change the situation in ways that are felt to be better by those who are concerned-and using so-called objective research methods, which tend to represent the situation in relationship to existing social norms.

Such tensions are particularly noticeable in education research, where measuring the children's school achievement implicitly places the problem (Bacchi 2007) with the student, and where examining socio-economic factors may frame the parents and communities as 'problematic'. Similar effects also concern more critical 
identity-focused research, to the extent that it is bound up with measures that segregate in an administrative sense, and which focus on some deficit or particular characteristic that can be measured or described in objective terms: establishing a norm for deviance.

Many of these arguments speak in favour of participatory action research, where the issues to be examined are defined by the people concerned themselves, and the focus is consequently placed on aspects or dimensions that are important in practice. In studies where Roma were interviewed (Malmö Stadskontor 2008; Liedholm and Lindberg 2010), it appeared that Swedish authorities and institutions such as schools spend little time engaging in real dialogue, and that project aims tend to be imposed in a top-down fashion, rather than being negotiated and reflected on collectively. Similar conclusions are reached by Hedberg (2013) in her ethnographic work. Against this background, possible developments for more relevant and equitable research formats include establishing programmes in educational leadership, research circles, as well as ethnographic case studies or different forms of participatory action research. At the same time, participatory approaches allow the local contexts to benefit from wider experiences, by connecting the research processes to academic researchers as well as to the practitioners.

\section{Conclusions}

In both Albania and Sweden, European Union policies supporting minority rights appear to have played a positive role over the past two decades. But the rights-based approach has not proved sufficient in addressing issues of equity and social justice. Although differences can be found between the two countries, in both Albania and Sweden, poverty appears to be a determining issue in lack of access for Roma to education. In Sweden, support measures specifically directed towards Roma mainly concern linguistic rights. At the same time, social divides are in fact widening rapidly in Sweden, and child poverty is increasing. Roma in Sweden are both a national minority and immigrant minorities, so while they are privileged by national minority legislation, they are marginalised as immigrants. For previously established Roma groups, although they have access to basic social security, housing segregation nevertheless affects quality of education and employment options. However, access to any form of social security is much more restricted among recently arrived immigrants, and without stable residence, schooling is frequently interrupted and becomes erratic.

Almost by definition, those Roma who differ from mainstream behaviour in Swedish society are at the same time most visible as Roma, and encounter both economic and educational difficulties. Inversely, there is also a clear intersection between the ethnic and socio-economic positions, where poverty and different physical signs of poverty, such as poor dental health are perceived as 'problematic' and as extraneous to Swedish society. Addressing the intersection of being Roma, poor and newly arrived is therefore particularly urgent. Here, a wider interpretation of human rights could support issues of livelihoods, housing and education, as well as restrictions of territoriality and the transnational dimension of the questions. 
In Albania, the question of Roma immigration is not as heatedly debated as in Sweden. Although Roma receive support as a 'vulnerable' group, poverty is not equally stigmatising in itself, and is more openly identified by authorities as a central issue concerning all citizens. Additional efforts could be made however, to create support structures such as counselling or encouraging the formation of cooperatives and viable SMEs, to ensure a more stable economic basis for Roma communities, and allowing their children to pursue extended educational pathways.

The segregating effects of special schools are clear (O'Nions 2010; Sjögren 2010), but there are equally excluding effects of studying in mainstream schools geared to measure what pupils already know-that is, recognising what they bring with them in terms of cultural capital that corresponds to majority norms and requirements (cf. Rodell Olgaç and Dimiter-Taikon 2013). Schools with a sorting function tend to categorise and group the students, rather than working to develop new knowledge and capacities. Such early categorisations can have a profound effect on children's sense of identity and self-esteem.

To avoid deficit perspectives (Valencia 1997; Garcia and Guerra 2004), and instead place focus on improving educational practices, we wish to argue that both ethnographic methods and participatory approaches offer powerful ways forward. Statistics on Roma education often present a bleak picture of the 'gap' that separates Roma from majority students. The interviews and interview studies described in this paper instead give clues and concrete indications concerning obstacles and factors for success that can provide a basis for improvements.

Instead of seeing Roma students as the 'problem', a relational conceptualisation makes it possible to consider what changes might be required in the situation as a whole, and to look at new forms of collaboration. A relational view of education builds on how learners relate to each other and to the teacher, as well as how they relate to the content, to the pedagogical approaches and to other elements of the learning setting. Thus teacher professionalism is not an absolute entity or solely a function of teacher training, but the teacher's competence will also depend on their full range of personal experiences and on who they are in relation to the learners. More teachers with a Roma background are needed, but also mediators and wellqualified tutors (Rodell Olgaç and Dimiter-Taikon 2013). Programmes training these professionals therefore become a priority.

In both Albania and Sweden, Roma associations and civil society organisations play a positive and empowering role. It is important however that community work is not simply seen in terms of implementing state policies in a top-down fashion, but that real space for dialogue with families and communities is provided. While official discourse suggests that Roma are today actively participating in Roma issues in concerned fora, interview studies with Roma instead draw a picture of lack of dialogue and community involvement (see for instance Hedberg 2013). It has here been argued that both ethnographic and participatory research approaches provide a way to change educational provisions in directions that better match the local conditions in each case, actively involving the community at every step.

This is not only to improve quality, but because the lack of voice in the organisation of learning is in itself an obstacle to education. This lack of involvement can position Roma learners as passively 'receiving education' or 
'receiving help' from the majority society and contributes to perceptions of being outsiders to the educational context - a perception which is held by the educators, the community, and the children themselves. Importantly, however, empowerment can be seen as an aim in its own right. Rather than merely being instrumental to education or an incidental means to an end, we might instead say that the main goal of education is precisely empowerment as a foundation for democratic societies. This is why reconsidering the methodological approaches used in research, making a shift from research on and about Roma issues, to research with and for Roma communities, can be a step in this direction.

Open Access This article is distributed under the terms of the Creative Commons Attribution 4.0 International License (http://creativecommons.org/licenses/by/4.0/), which permits unrestricted use, distribution, and reproduction in any medium, provided you give appropriate credit to the original author(s) and the source, provide a link to the Creative Commons license, and indicate if changes were made.

\section{References}

Alexiadou, N., Dovemark, M., Erixon-Arreman, I., Holm, A. S., Lundahl, L., \& Lundström, U. (2016). Managing inclusion in competitive school systems: The cases of Sweden and England. Research in Comparative and International Education, 11(1), 13-33.

Avery, H. (2015). Teaching in the edgelands of the school day: The organisation of Mother Tongue Studies in a highly diverse Swedish primary school. Power and Education, 7(2), 239-254.

Bacchi, C. (2007). The ethics of problem representation: Widening the scope of ethical debate. Policy and Society, 26(3), 5-20.

Baraku, I., \& Hoxhaj, E. (2015). The protection of the rights of Roma community, social policies and Albanian legal and institutional framework for their implementation. European Journal of Social Sciences Education and Research, 1(4), 73-79.

Bunar, N. (2010). The geographies of education and relationships in a multicultural city: Enrolling in high-poverty, low-performing urban schools and choosing to stay there. Acta Sociologica, 53(2), 141-159.

Cabiri, Y., Hasantari, A., Rama, L., Bajrami, I., Ziu, D., Xega, G., et al. (2013). Civil society monitoring report on the implementation of the national Roma integration strategy and decade action plan in 2012 in Albania. Budapest: Decade of Roma Inclusion Secretariat Foundation.

Center for Social Rights. (2016). Report to the special rapporteur on minority issues of the office of the high commissioner for human rights: On the situation of the migrant Roma community in Malmö, Sweden. Malmö: Center for Social Rights.

Curcic, S., Miskovic, A., Plaut, S., \& Ceobanu, C. (2014). Inclusion, integration or perpetual exclusion? a critical examination of the decade of Roma inclusion, 2005-2015. European Educational Research Journal, 13(3), 257-267.

Delegationen för romska frågor. (2010). Romers rätt - en strategi för romer $i$ Sverige (Roma rights - a strategy for Roma in Sweden). SOU 2010:55. Stockholm: Delegationen för romska frågor.

Elias, S. B. (2010). Regional minorities, immigrants, and migrants: The reframing of minority language rights in Europe. Berkley Journal of International Law (BJIL), 28(1), 261-312.

European Commission (2011). Commission staff working paper. Albania 2011 progress report. Communication from the commission to the European parliament and the council. Enlargement strategy and main challenges 2011-2012. Brussels: European Commission.

European Commission. (2015). Commission staff working document Albania 2015 report. Brussels: European Commission.

Garaz, S. (2014). Helping the marginalised or supporting the elite? Affirmative action as a tool for increasing access to higher education for ethnic Roma. European Educational Research Journal, 13(3), 295-311.

Garcia, S. B., \& Guerra, P. L. (2004). Deconstructing deficit thinking working with educators to create more equitable learning environments. Education and Urban Society, 36(2), 150-168. 
Gorski, P. C. (2012). Perceiving the problem of poverty and schooling: Deconstructing the class stereotypes that mis-shape education practice and policy. Equity \& Excellence in Education, 45(2), 302-319.

Government Bill (1998/1999). Nationella minoriteter i Sverige (National minorities in Sweden). p. 143.

Government Offices of Sweden. (2013). Sweden's report to the Council of Europe on the European charter for regional or minority languages. Stockholm: Government Offices of Sweden.

Hedberg, A. S. (2013). A national strategy for Roma inclusion 2012-2032: Some notes on marginalization, participation and exclusion from a Roma activist perspective. Presented at the Conference of the Swedish Anthropological Association (SANT), Uppsala, 26-28 April, 2013.

INSTAT (2011). Census/1.1.13. Retrieved on 25 October 2016 from http://www.instat.gov.al/al/census/ census-2011/t\%C3\%AB-dh\%C3\%ABnat-e-census-2011.aspx.

Kamberi, E., Martinovic, B., \& Verkuyten, M. (2015). Life satisfaction and happiness among the Roma in central and southeastern Europe. Social Indicators Research, 124(1), 199-220.

Kelly, K., \& Van der Riet, M. (2001). Participatory research in community settings: Processes, methods and challenges. In M. Seedat, S. Lazarus, \& N. Duncan (Eds.), Theory, method and practice in community psychology: South African and other perspectives (pp. 159-188). Cape Town: Oxford University Press.

Liedholm, M., \& Lindberg, G. (2010). Romska barn i skolor (Roma children at school). Lund: Delegationen för romska frågor.

Malmö Stadskontor. (2008). Romers situation i Malmö. En rapport om Malmös minoritetspolitik utifrån romernas perspektiv (The situation of Roma in Malmö: A report on the minority policy of Malmö from the perspective of Roma). Malmö: Malmö Stadskontor.

May, S. (2014). Justifying educational language rights. Review of Research in Education, 38(1), $215-241$.

Ministry of Culture (2014). "Den mörka och okända historien"-en vitbok om övergrepp och kränkningar av romer och resande i Sverige under 1900-talet Ds 2014:8 ("The dark and unknown history"-A white paper on abuse and violations towards Roma and travellers in Sweden during the 20th century). Stockholm: Ministry of Culture.

Miskovic, M., \& Curcic, S. (2016). Beyond inclusion: Reconsidering policies, curriculum, and pedagogy for Roma students. International Journal of Multicultural Education, 18(2), 1-14.

Obucina, O. (2014). paths into and out of poverty among immigrants in Sweden. Acta Sociologica, 57(1), $5-23$.

O’Nions, H. (2010). Divide and teach: Educational inequality and the Roma. The International Journal of Human Rights, 14(3), 464-489.

Ohlsson, A. 1., \& Fakir, I. (2015). Nya rum för socialt medborgarskap. Om vetenskap och politik $i$ "Zigenarundersökningen"-en socialmedicinsk studie av svenska romer 1962-1965 (New spaces of social citizenship. On science and policy in the "Gypsy Study" — a socio-medical study of Swedish Roma 1962-1965). Ph.D. Dissertation. Växjö: Linnaeus University.

Palosuo, L. (2008). En inventering av forskningen om romer i Sverige. Ett uppdrag från Delegationen för romska frågor (An inventory of research on Roma in Sweden: Commissioned by the Delegation for Roma Issues). Uppsala: Uppsala universitet, Centrum för multietnisk forskning.

Rodell Olgaç, C. (1999). Interkulturella arbetssätt i en förberedelseklass: att lära av sina romska och somaliska elever (Intercultural approaches in a preparatory class: To learn from your Roma and Somalian pupils). In M. Axelsson (Ed.), Tvåspråkiga barn och skolframgång: mångfalden som resurs (Bilingual children and school success: Diversity as a resource) (pp. 61-79). Spånga: Rinkeby Institute for Language Research.

Rodell Olgaç, C., \& Dimiter-Taikon, A. (2013). “Mamma, ska jag säga att jag är rom?” En kartläggning av romska barns och eleversskolsituation i fem pilotkommuner för Skolverket ("Mother, should I say that I am Roma?" Mapping the school situation of Roma children and pupils in five pilot municipalities for the Swedish National Agency for Education). Stockholm: Södertörns högskola.

Rodell Olgaç, C., \& Dimiter-Taikon, A. (2016). Romsk brobyggarutbildning med inriktning mot skolan 2012-2015 Högre utbildning, social mobilitet och interkulturellt capital (Roma mediator programme oriented towards schools 2012-2015: Higher education, social mobility and intercultural capital). Stockholm: Södertörns högskola.

Scarpa, S. (2015). The spatial manifestation of inequality: Residential segregation in Sweden and its causes. Ph.D. diss. Växjö: Linnaeus University.

SFS (2009a:600). Language Act.

SFS (2009b:724). Act on National Minorities and National Minority Languages.

SFS (2010:800). Education Act. 
SFS (2011:185). Education Ordinance.

SFS (2014:458). Lag om ändring i skollagen (2010:800) (Law on changes in the Education Act 2010:800).

Sjögren, D. (2010). Den säkra zonen: Motiv, åtgärdsförslag och verksamhet $i$ den särskiljande utbildningspolitiken för inhemska minoriteter 1913-1962 (The safety zone: Motives, suggested measures and activities in the separative education policy targeted at native minorities [in Sweden] 1913-1962). Ph.D. diss. Umeå: Umeå university.

Stigendal, M., \& Östergren, P. O. (Eds.). (2013). Malmös väg mot en hållbar framtid: hälsa, välfärd och rättvisa (The path of Malmö towards a sustainable future: health, welfare and justice). Malmö: Commission for a socially sustainable Malmö.

Valencia, R. (Ed.). (1997). The evolution of deficit thinking. London: Falmer.

Xhillari, L., \& Cici, J. (2016). Social housing and situation of Roma minority in Albania. Academic Journal of Business, Administration, Law \& Social Sciences., 2(1), 184-187.

Xhumari, M., \& Dibra, S. (2016). Access to the Albanian VET System: social, individual and schoolbased barriers. European Journal of Education., 51(3), 320-332. 